Article

\title{
Bathymetry of Northwest Greenland Using “Ocean Melting Greenland" (OMG) High-Resolution Airborne Gravity and Other Data
}

\author{
Lu An ${ }^{1, *}$, Eric Rignot ${ }^{1,2}, * \mathbb{C}$, Romain Millan ${ }^{1} \mathbb{C}$, Kirsty Tinto $^{3}$ and Josh Willis ${ }^{2}$ \\ 1 Department of Earth System Science, University of California, Irvine, CA 92697, USA; millanr1@uci.edu \\ 2 Jet Propulsion Laboratory, California Institute of Technology, Pasadena, CA 91109, USA; \\ joshua.k.willis@jpl.nasa.gov \\ 3 Lamont-Doherty Earth Observatory, Earth Institute at Columbia University, Palisades, NY 10027, USA; \\ tinto@ldeo.columbia.edu \\ * Correspondence: lan3@uci.edu (L.A.); erignot@uci.edu (E.R.); Tel.: +1-949-824-3739 (L.A.)
}

Received: 20 November 2018; Accepted: 7 January 2019; Published: 11 January 2019

\begin{abstract}
Marine-terminating glaciers dominate the evolution of the Greenland Ice Sheet (GrIS) and its contribution to sea-level rise. Widespread glacier acceleration has been linked to the warming of ocean waters around the periphery of Greenland but a lack of information on the bathymetry of the continental shelf and glacial fjords has limited our ability to understand how subsurface, warm, salty ocean waters of Atlantic origin (AW) reach the glaciers and melt them from below. Here, we employ high-resolution, airborne gravity data (AIRGrav) in combination with multibeam echo sounding (MBES) data, to infer the bathymetry of the coastal areas of Northwest Greenland for NASA's Ocean Melting Greenland (OMG) mission. High-resolution, AIRGrav data acquired on a $2 \mathrm{~km}$ spacing, $150 \mathrm{~m}$ ground clearance, with $1.5 \mathrm{mGal}$ crossover error, is inverted in three dimensions to map the bathymetry. To constrain the inversion away from MBES data, we compare two methods: one based on the Direct Current (DC) shift of the gravity field (absolute minus observed gravity) and another based on the density of the bedrock. We evaluate and compare the two methods in areas with complete MBES coverage. We find the lowest standard error in bed elevation $( \pm 60 \mathrm{~m})$ using the DC shift method. When applied to the entire coast of Northwest Greenland, the three-dimensional inversion reveals a complex network of connected sea bed channels, not known previously, that provide natural and varied pathways for AW to reach the glaciers across the continental shelf. The study demonstrates that the gravity approach offers an efficient and practical alternative to extensive ship mapping in ice-filled waters to obtain information critical to understanding and modeling ice-ocean interaction along ice sheet margins.
\end{abstract}

Keywords: remote sensing; gravity; bathymetry; Greenland; glaciology; ice-ocean interaction; climate change

\section{Introduction}

The Greenland Ice Sheet (GrIS) has been losing mass and contributing to sea-level rise more than 1 $\mathrm{mm} / \mathrm{yr}$ in the last two decades [1-4]. The total mass loss is widespread, and one third is from northwest (NW) Greenland [5]. The mass loss is a combination of increased ice discharge of its marine-terminating glaciers and decreased surface mass balance from enhanced surface melt. Wide spread acceleration of glaciers has taken place [6] as subsurface, warm, salty, Atlantic Water (AW) spread more vigorously around the periphery of Greenland [7-9]. Subsurface ocean waters at the front of these glaciers became warmer, the melt rates of their calving faces increased, causing them to retreat and experience less buttressing, which in turn allowed the glaciers to speed-up [10-12]. Bathymetry regulates the degree 
with which ocean heat is transmitted to the glaciers [13-15] and hence how the glaciers will evolve in the future. Until recently, the bathymetry of most glacial fjords in NW Greenland had not been surveyed. The most recent compilation of ocean bathymetry, the International Bathymetric Chart of the Arctic Ocean (IBCAOv3), does not include glacier fjords [16].

To improve our understanding of ice-ocean interaction in Greenland, NASA launched in 2015 a five-year mission named 'Ocean Melting Greenland' (OMG) that includes bathymetry mapping with multibeam echo sounder (MBES) and airborne high-resolution gravity, airborne high-resolution surface topography, and physical properties (temperature, salinity, and conductivity) of the ocean waters from air-dropped probes [14]. As a first result, Morlighem et al. [17] compiled a novel bed topography of the Greenland Ice Sheet, BMv3, that uses a mass conservation method on land, forced by the OMG bathymetric data at the ice margin. Off shore, the mass conservation approach does not apply, hence BMv3 combines IBCAOv3, OMG MBES, and other recent data sets. Shipborne MBES surveys cannot be extended across the entire continental shelf because the area to be surveyed is too large and the mapping task would be too time consuming and expensive. Airborne, high-resolution gravity data offers an alternative to survey large areas at a reduced spatial resolution $[18,19]$. The challenge of the gravity data inversion is to properly constrain the underlying geology which influences the absolute gravity field [20,21].

Here, we present an approach that fills bathymetric gaps in NW Greenland using OMG airborne gravity and a dense network of MBES data. We employ a 3-D inversion of gravity data constrained by MBES data off shore and BMv3 reconstruction on shore. We evaluate the uncertainty of the inferred bed elevation and compare the results with earlier mappings. We discuss the implications of the new product on our understanding of ocean circulation and ice-ocean interaction in NW Greenland.

\section{Data and Methods}

\subsection{Airborne Gravity Data}

The OMG mission collected gravity data on the continental shelf using the Sander Geophysics Limited (SGL)'s Airborne Inertially Referenced Gravimeter (AIRGrav). The survey of NW Greenland was carried out in April 2016 (Figure 1), mostly over the open ocean, using SGL's Cessna Grand Caravan 208B, a fixed-wing aircraft, at a survey speed of 110 knots, with a $2 \mathrm{~km}$ line spacing, and $150 \mathrm{~m}$ above the sea surface. Accelerometer data are recorded at $128 \mathrm{~Hz}$ and down sampled to $2 \mathrm{~Hz}$ during processing. SGL proprietary software is used for processing [22]. Eötvös, theoretical gravity, free-air, static, and level corrections are applied on the data to yield free-air gravity anomalies [23], which we refer to as OMG gravity data in the remainder of the paper. With a 28-s half-wavelength filter, we expect a nominal resolution of $1.6 \mathrm{~km}$; however due to additional filtering of the data to reduce noise, the practical resolution of the data is 1.8 to $2 \mathrm{~km}$. The gravity data has overall RMS of crossover differences of $1.5 \mathrm{mGal}$. The data are gridded using a minimum curvature algorithm that averages all values within $500 \mathrm{~m}$ grid cell size and interpolates the data between survey lines. Low pass filtering is applied to the grid to reduce residual noise, reconcile data at intersections of cross cutting lines, and reduce aliasing effects from sub-sampling the gravity signal perpendicular to survey lines. Final data are filtered with a $1 \mathrm{~km}$ half-wavelength grid filter. We use gridded gravity data for the inversion because it is the preferred data format for the inversion and because 2-D filtering of the data employed during data gridding lowers the data noise compared to line data.

\subsection{Multibeam Echo Sounding Data}

Bathymetry data along the coastline of Greenland include OMG MBES data collected in July-September 2015 for the OMG mission on the M/V Cape Race, additional MBES data collected in August 2017 onboard the S/Y Ivilia, and data from other projects [17] (Figure 1a). The S/Y Ivilia employed a Kongsberg EM710 sonar that processed the data with the Seafloor Information System (SIS), a real-time software designed to be the user interface and the real-time data processing system 
produced by Kongsberg Maritime. The R/V Cape Race operated a Reson Seabat 7160 (Teledyne RESON Inc., Camarillo, CA, USA) sonar with CARIS HIPS processing software version 9.0 and QINsy operating software version 8.10. The sonars produce an angular swath of beams to the port and starboard sides in a single ping to effectively map a corridor with a width approximately 3-4 times the water depth. Positioning was supplied via a NavCom SF-3050 Global Navigation Satellite System (GNSS) with StarFire Corrections with an accuracy of $10 \mathrm{~cm}$ horizontally and $15 \mathrm{~cm}$ vertically. Pitch, roll, heave, and heading are used to correct for the attitude of the sonar. Water Conductivity, Temperature and Depth (CTD) were collected in September and October 2016 and October 2017 using an AML Oceanographic Minos X CTD (British Columbia Canada) in thick brash/sea ice conditions and a Valeport Rapid CTD (Teledyne Oceanscience, Carlsbad, CA, USA) in ice-free ocean waters [24]. CTD data collected along the MBES survey lines were used to calculate the sound velocity and correct the data for refraction [25] using the CARIS or SIS software version 4.3.2.

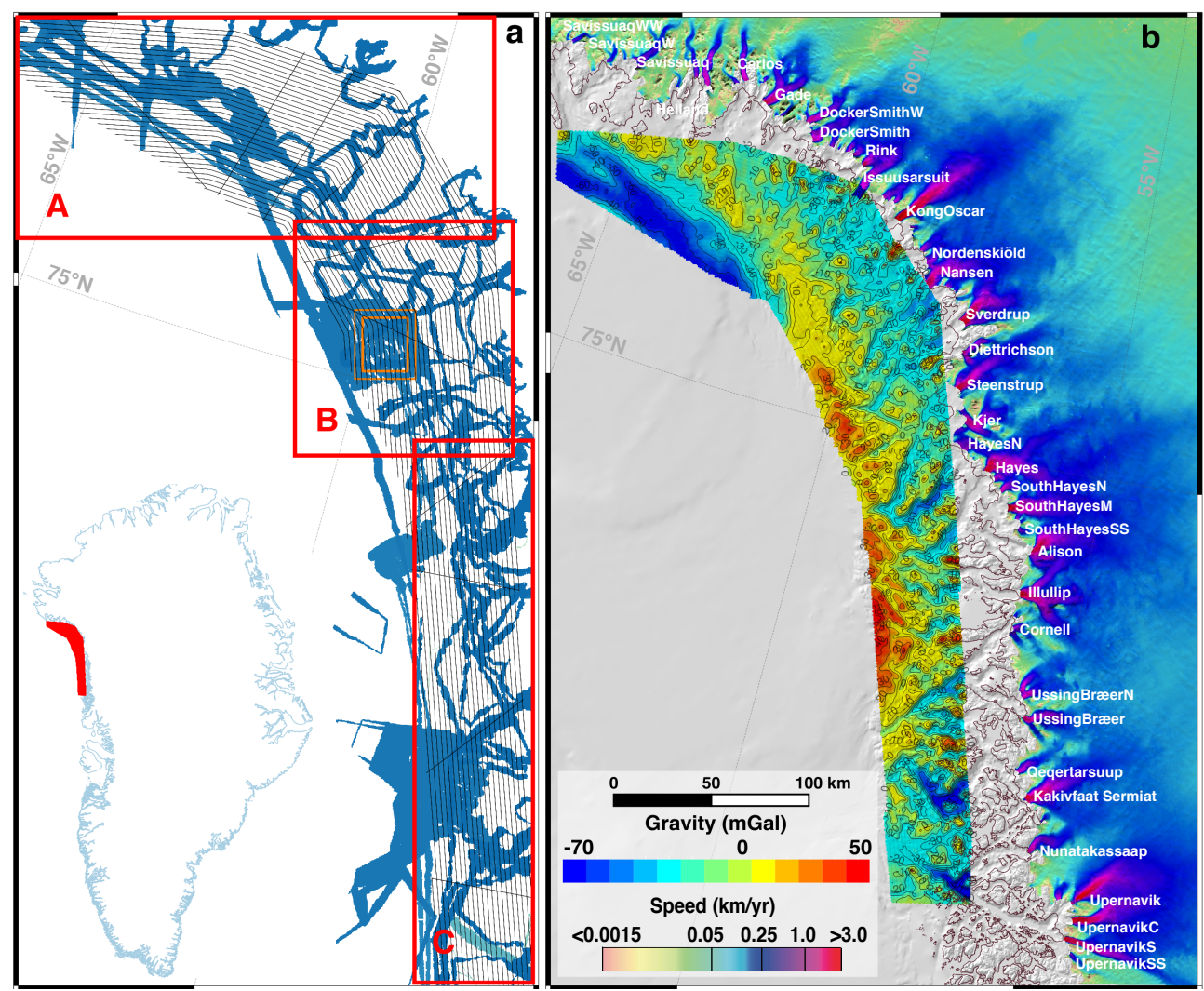

Figure 1. (a) Survey lines (black thin line) of OMG airborne gravity in Northwest (NW) Greenland, with multibeam echo sounding (MBES) data (blue line). Three regions A-C (red box) divide the domain. The orange box delineates a test area with complete MBES and gravity data coverage. Inset shows the location of the surveyed domain in Greenland. (b) Free-air gravity anomalies in mGal $\left(1 \mathrm{mGal}=10^{-5} \mathrm{~m} / \mathrm{s}^{2}\right)$ color coded from blue $(-70 \mathrm{mGal})$ to red $(+50 \mathrm{mGal})$ with $10 \mathrm{mGal}$ contours in black overlaid on a shaded relief of the bed elevation from BMv3. Ice velocity on land ice with glacier names.

\subsection{Inversion Methods}

Survey domain. We divide the survey domain into parts A-C to ease the computation (Figure 1). To invert the gravity data, we use the Geosoft GM-SYS 3-D software version 9.0, which implements Parker [26]'s method to calculate the gravity anomaly caused by an uneven, uniform layer of material 
by means of a series of Fourier transforms and modify it iteratively to minimize the misfit between calculated and observed gravity. The Fourier transform of the gravity field is expressed as:

$$
F(\Delta g)=-2 \pi G \rho \mathrm{e}^{-k z_{0}} \sum_{n=1}^{\infty} \frac{k^{n-1}}{n !} F\left[h^{n}(x)\right]
$$

where $F(\Delta g)$ is the Fourier transform of the gravity anomaly, $G$ is the universal gravitational constant, $\rho$ is the density contrast across the interface, $k$ is the wave number, $h(x)$ is the depth to the interface (positive downward), and $z_{0}$ is the mean depth of the horizontal interface. We model the inversion domain as three horizontal layers: (1) a solid ice layer with a density of $0.917 \mathrm{~g} / \mathrm{cm}^{3}$; (2) an ocean water layer with a density of $1.028 \mathrm{~g} / \mathrm{cm}^{3}$; and (3) a rock layer with a uniform density of $2.67 \mathrm{~g} / \mathrm{cm}^{3}$.

To obtain regularly gridded gravity data in the rectangular domain of the inversion and avoid edge effects [19], we pad the observed gravity data with gravity simulations from a "first-guess" bathymetry model that assumes a uniform bedrock density. The initial bed solution is BMv3. DC refers to a direct current voltage, which is a term originally in electronics. When describing a periodic function in the time domain, DC shift is the mean amplitude of the waveform. Here, the Direct Current shift, or "DC shift", is the mean difference between the measured gravity and the absolute modeled gravity $[27,28]$. In the gravity model, the DC shift accounts for the difference between the absolute gravity of the Earth and the gravity field in our inversion domain. We calculate the DC shift, correct the observations with it, and then add the modeled gravity to fill in the observational gaps. This procedure minimizes the impact of areas outside the surveyed area. For instance, gravity anomalies associated with mountain blocks [19] influence the gravity field many kilometers away. By accounting for this effect, we minimize the impact of observational gaps on the solution of the inversion. When merging the observations with the modeled gravity, we allow a $1500 \mathrm{~m}$ wide (horizontal) transition between observations and modeled gravity to enable a smooth transition that preserves the observations.

To perform the inversion, we compare two different procedures. One is based on the interpolation of the point to point DC shift obtained within our model domain assuming a uniform bedrock density. Another procedure is based on an interpolation of density of bedrock assuming a uniform value of DC shift instead. The second procedure involves an additional inversion for bedrock density.

DC shift inversion. Over a small area uniform in geology, the DC shift should be uniform, but over an extensive area with varying geology, the DC shift will vary spatially. Here, we calculate the DC shift by comparing observations with the modeled gravity in areas we have MBES data. The modeled gravity is calculated using a forward model with BMv3 as the initial solution. We assume a bedrock density of $2.67 \mathrm{~g} / \mathrm{cm}^{3}$ (Figure 2b). We employ a minimum curvature algorithm to interpolate the DC shift values in between the MBES data (Figure 2c). We then add the DC shift values to the observations (Figure 2d) and merge the result with the forward modeled gravity. We allow a $1500 \mathrm{~m}$ wide transition between MBES data and non-surveyed areas. In the transition region, the inversion conducted using Geosoft is modulated by a factor varying linearly from 0 (no inversion) to 1 (full inversion). No data inversion is performed on land and MBES data available (inversion factor is 0 ). We only invert the gravity data on the portions of ocean where is no prior bathymetry (inversion factor of 1). The long-wavelength contributions to the observed field, which do not influence the response of the gravity field to bathymetric variation, are successfully removed by this technique.

Density inversion. We start from a uniform DC shift calculated as the average difference between the airborne data and a forward model using a density of $2.67 \mathrm{~g} / \mathrm{cm}^{3}$ over the areas we have MBES data. We add the mean DC shift value to the observations (Figure 2b) and fill the gaps with the forward model. We perform an inversion for the density that produces a modeled gravity that best matches the observations where we have MBES data. We interpolate the inferred densities using a minimum curvature algorithm. We then perform an inversion for the bed elevation, using the average value of the DC shift, and the map of density of bedrock. 


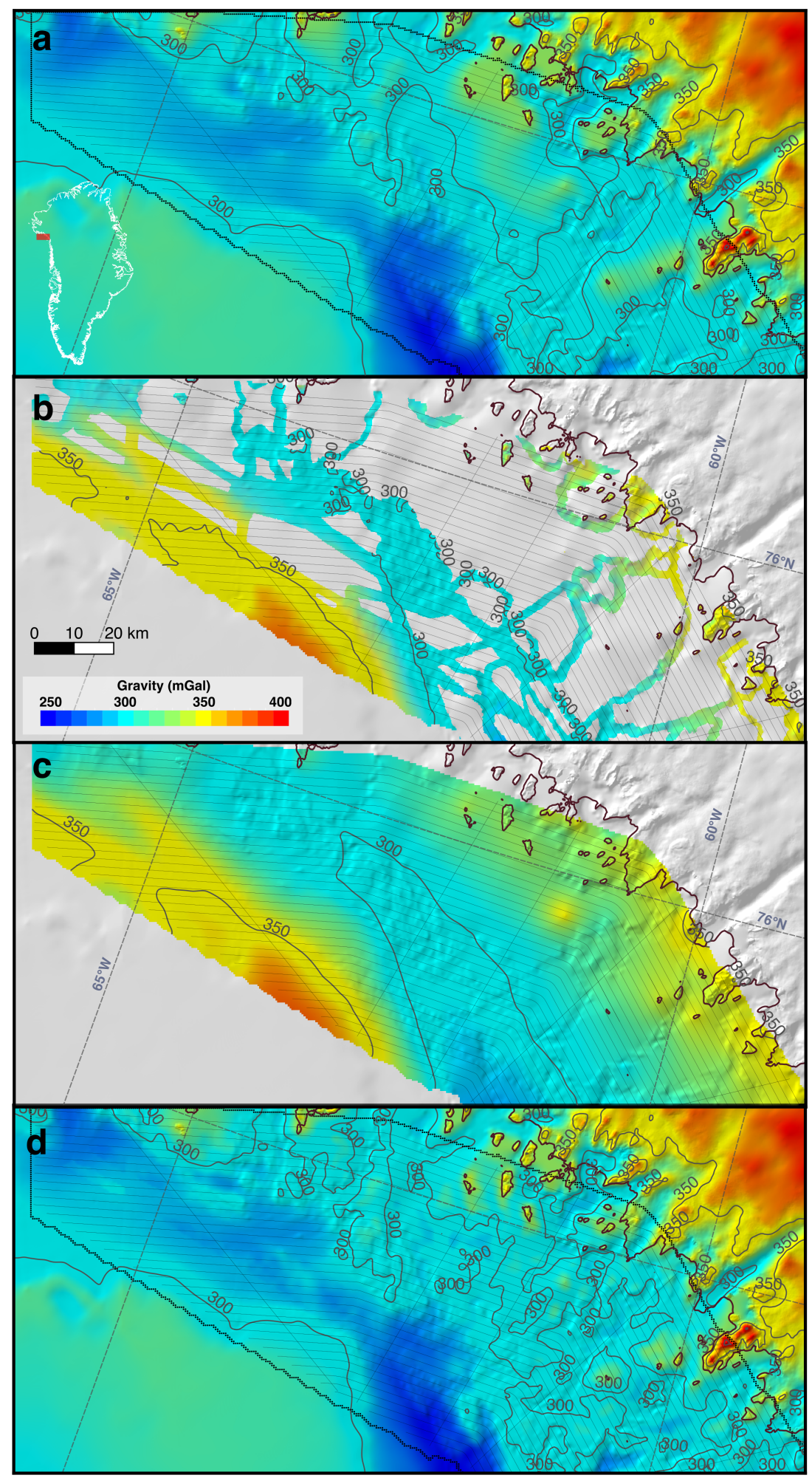

Figure 2. (a) Forward model gravity field of block A using the BMv3 solution. (b) DC shift calculated by differencing the forward model with observations where we have MBES data. (c) Interpolated DC shift over the entire area using a minimum curvature algorithm. (d) Input gravity to the inversion model after the DC shift is added to the observations. Black dash lines represent the gravity coverage of block $\mathrm{A}$ in $(\mathbf{a}, \mathbf{d})$. 
Evaluation of inversion schemes. During the inversion, the unknown sea floor depth is modified iteratively to minimize the residuals between modeled and observed gravity. The iteration stops when the standard deviation of the error is lower than a user-provided value, i.e., $0.1 \mathrm{mGal}$ $\left(1 \mathrm{mGal}=10^{-5} \mathrm{~m} / \mathrm{s}^{2}\right)$. We compare the two methods (DC shift vs density) in part B (orange box in Figure 1) where we have complete MBES coverage, i.e., we know the bed solution. We constrain the inversion using data only from the periphery of the domain, or a region $3 \mathrm{~km}$ wide (Figure 3 ). To evaluate the inversions, we calculate the average difference and standard deviation between the result and the correct value of the bed elevation. We also compare the data along specific profiles. One profile, $\mathrm{A}-\mathrm{A}^{\prime}$, lines up with an east-west trough perpendicular to the gravity lines. A second line B-B' follows one survey line (Figure $4 \mathrm{~g}-\mathrm{j}$ ).

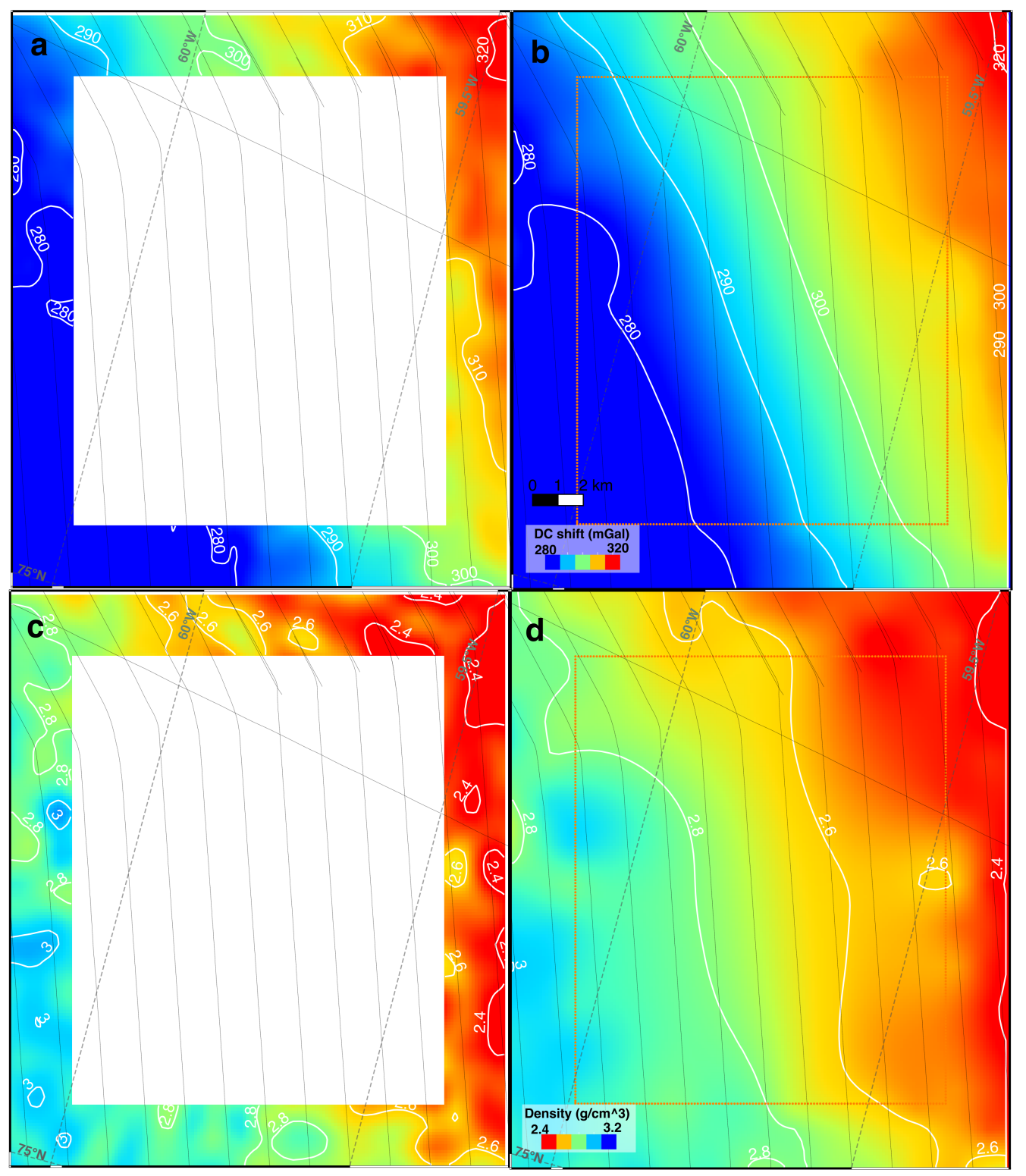

Figure 3. Test area in Figure 1a (a) DC shift along the periphery of test area in B. (b) DC shift interpolated from the periphery using a minimum curvature algorithm, with $10 \mathrm{mGal}$ contours in white. (c) Density values along the periphery of test area in B. (d) Density values interpolated from the periphery using a minimum curvature algorithm, with $0.2 \mathrm{~g} / \mathrm{cm}^{3}\left(1 \mathrm{~g} / \mathrm{cm}^{3}=1000 \mathrm{~kg} / \mathrm{m}^{3}\right)$ contours in white. 

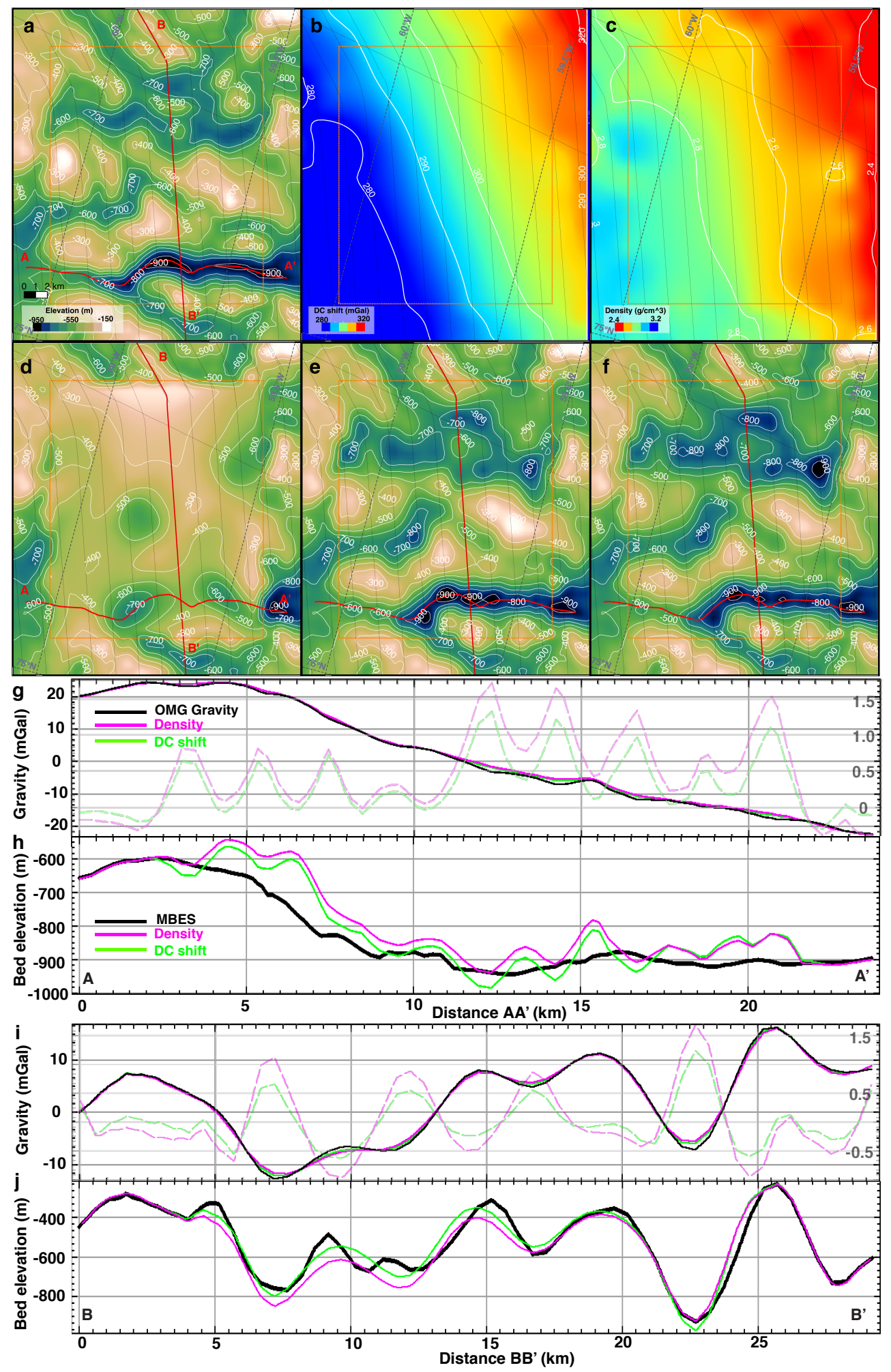

Figure 4. Test area in Figure 1a (a) Bed elevation from MBES data, profile A-A' (east-west) along a trough, and B-B' (north-south) along a survey line, with 100-m bed elevation contours. (b) DC shift map interpolated from the periphery (i.e., outside orange thin box). (c) Density map interpolated from the periphery. (d) Initial bed elevation from IBCAOv3 (inside orange thin box). (e) Inferred bed elevation using DC shift map (b). (f) Inferred bed elevation using Density map (c). (g,i) Comparison of the OMG observed gravity (black line) with gravity model calculated gravity (solid line), and gravity misfit (dash line) along profile A-A' and B-B' . (h, j) Comparison of the MBES bed elevation data (black line) with inferred bed from gravity along profile $\mathrm{A}-\mathrm{A}^{\prime}$ and $\mathrm{B}-\mathrm{B}^{\prime}$. 


\subsection{Error in Bed Elevation}

The gravity data are gridded using a minimum curvature algorithm that averages all values within $500 \mathrm{~m}$ grid cell size and interpolates the data in between survey lines (results showed in Figure 4g-j). We tested several interpolations beside the standard minimum curvature method. We also used a minimum curvature with a low pass desampling filter of $2 \mathrm{~km}$, and a Kriging method with a spherical variogram model. The mean error and standard deviation from these methods are $166.0 \pm 82.5 \mathrm{~m}$ and $135.2 \pm 68.3 \mathrm{~m}$, which are larger than the minimum curvature method.

A product of the gravity inversion is a map of the gravity misfit, which is the difference between modeled and observed gravity [20]. Using a forward model, we calculate the change in gravity field caused by a $100-\mathrm{m}$ change in water depth. We find $5 \mathrm{mGal}$ per $100 \mathrm{~m}$ of water. We could use this conversion ratio to translate the gravity misfit from $\mathrm{mGal}$ to meters and obtain an uncertainty in bed elevation (Figure 5c).

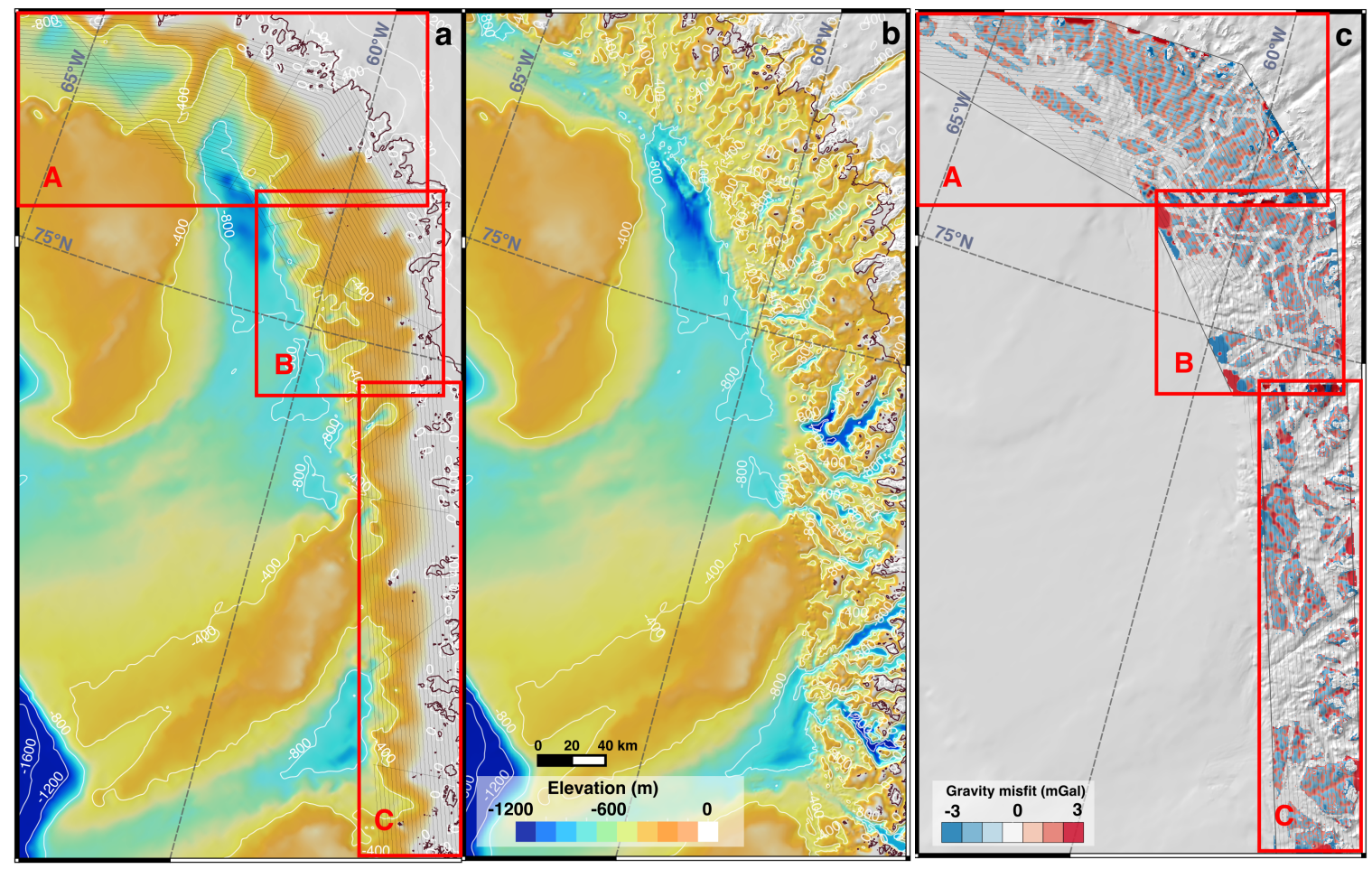

Figure 5. (a) Original bed elevation from IBCAOv3 [16]. (b) Bed elevation combining MBES data, OMG gravity inversion, and BMv3 [17]. $400 \mathrm{~m}$ elevation contours in white. Brown line is the ice-ocean boundary. (c) Gravity misfit (mGal) compared with the OMG gravity data inside the inversion domain (thin gray line) color coded between -3 and $+3 \mathrm{mGal}$. Gravity flight tracks are thin black lines.

\section{Results}

The observed gravity anomalies within the survey area vary from $-75 \mathrm{mGal}$ in the fjords to $51 \mathrm{mGal}$ on surrounding mountains and islands (Figure 1b). As expected, the inferred bed elevation is positively correlated with the gravity anomaly, i.e., a low bed elevation corresponds to a negative gravity anomaly and vice versa (Figure 5b). Compared with IBCAOv3 (Figure 5a), the sea floor is significantly deeper and more complex. We obtain water depths several hundred meters deeper on average and we find a network of deep seafloor channels on the continental shelf that are not present in IBCAOv3 due to the absence of prior data. 
Comparing the bed elevation along $\mathrm{A}-\mathrm{A}^{\prime}$ and $\mathrm{B}-\mathrm{B}^{\prime}$ (Figure $4 \mathrm{~g}$, Table 1 ), we find a mean error of the inversion ranging from -20 to $+50 \mathrm{~m}$ and a standard deviation ranging from 39 to $50 \mathrm{~m}$. Over the entire domain, the mean error is -13 to $-41 \mathrm{~m}$ with a standard deviation of 62 to $68 \mathrm{~m}$. The best solution is obtained using the DC shift algorithm, especially along the survey line B-B'. Along trough A- $\mathrm{A}^{\prime}$, we note undulations of $\pm 60 \mathrm{~m}$ with a wavelength of $2 \mathrm{~km}$ in both the density and DC shift solutions that reflect the line spacing of the survey and half wavelength of the gravity data. Please note that these undulations are not present along the survey line B- $\mathrm{B}^{\prime}$.

Table 1. Comparison of bed elevation (mean \pm standard deviation) from the DC shift and the density algorithms along profile $\mathrm{A}-\mathrm{A}^{\prime}, \mathrm{B}-\mathrm{B}^{\prime}$ and the entire domain (total) to MBES data.

\begin{tabular}{ccc}
\hline Profile & Inversion & Mean $(\mathbf{m}) \pm$ Standard Deviation $(\mathbf{m})$ \\
\hline A-A $^{\prime}$ & DC shift & $32.7 \pm 46.4$ \\
A-A & Density & $50.5 \pm 47.4$ \\
B-B $^{\prime}$ & DC shift & $2.7 \pm 39.0$ \\
B-B $^{\prime}$ & Density & $-20.5 \pm 49.6$ \\
Total & DC shift & $-13.1 \pm 62.1$ \\
Total & Density & $-41.2 \pm 67.5$ \\
\hline
\end{tabular}

We note that the DC shift map and density map (Figure $4 b, c$ ) show very similar variations across the model-space, i.e., they might play comparable role in the inversion. Based on our evaluation, the DC shift shows slightly better results, with a bathymetry that is better centered on the true depth of the seafloor (Table 1, Figure 4). Hence, we use it for the remainder of the study and assume a nominal uncertainty in bed elevation of $\pm 60 \mathrm{~m}$. We also posit that the use of a reasonable interpolation scheme in between the MBES plays a crucial role in the inversion results.

In the red box of part A in Figure 6, the gravity inversion improves bed mapping significantly compared to IBCAOv3. We obtain better topographic details and identify channel connectivity, i.e., the depth of troughs carved on the seafloor is not interrupted by shallow passages but generally remains consistently deep. The new bathymetry reveals a network of connected channels on the continental shelf. We attribute their presence to bedrock erosion from prior advances of glaciers in colder periods. Most of the channels are deep enough $(>300 \mathrm{~m})$ to enable the advection of warm, subsurface, salty AW to the glaciers, i.e., they are connected over distances long enough to transmit AW to the glacier fronts [29]. In the new map of part A, we detect prominent seafloor channels in front of Rink glacier (Figure 6b).

In Part B north of Alison Glacier, we had a dense network of MBES measurements so the improvements from the gravity inversion are less apparent (Figure 7). Within the red box areas in the figure, however, we find places where channel connectivity is much more complex compared to the previous maps.

In part C (Figure 8), we find that two deep, wide, adjacent channels on the inner shelf near $74.5^{\circ} \mathrm{N}$, $57^{\circ} \mathrm{W}[14]$ that are now connected from the gravity inversion (Figure 8). We find consistent seafloor channels connected with the glaciers over a domain spanning from Hayes to Illullip glaciers. In the southern part, we find a 600-m deep channel in a nearly flat area according to the prior mappings (Figure 8a). 


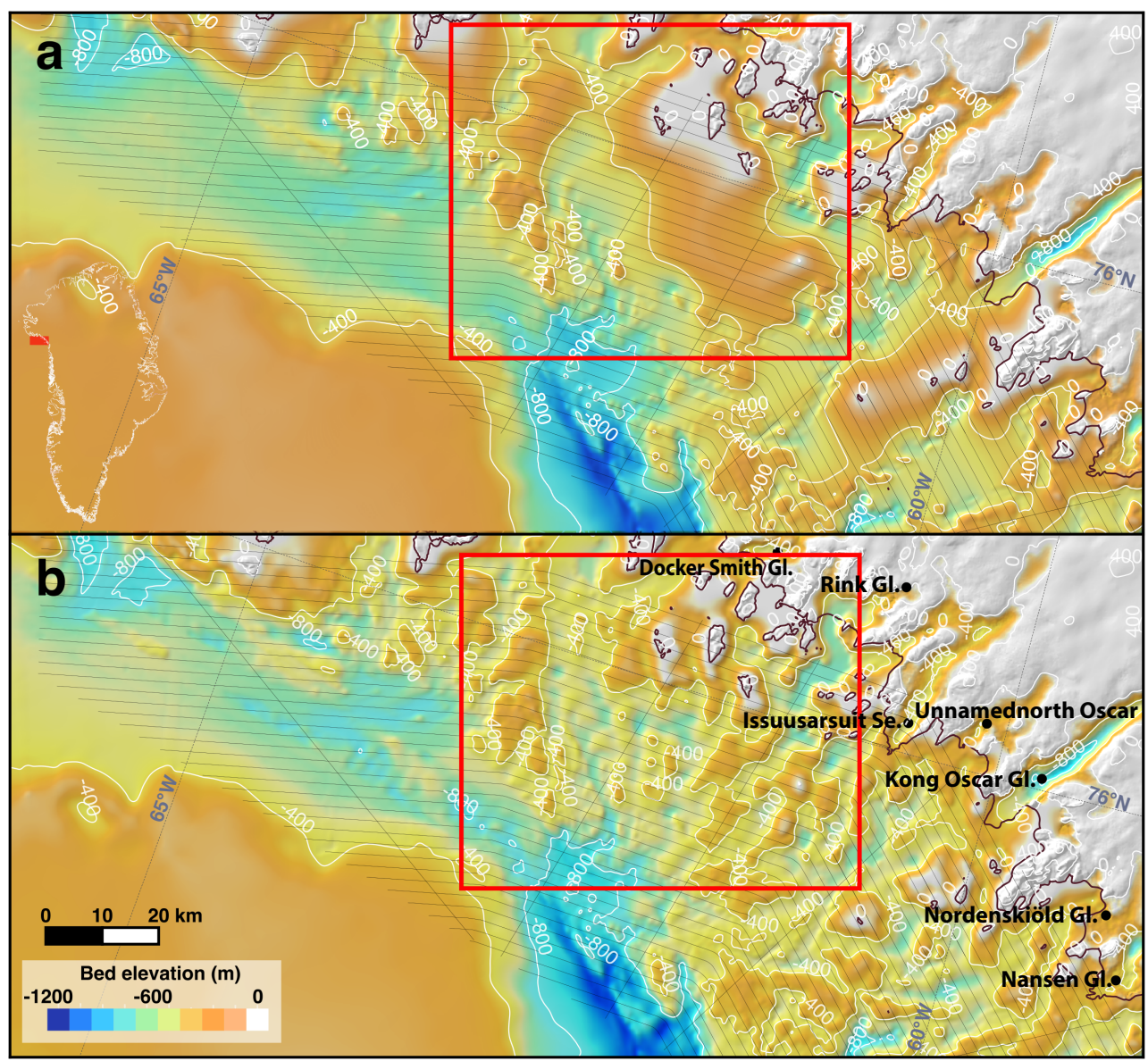

Figure 6. Region A in Figure 1a (a) Original bed elevation combining MBES measurements, IBCAOv3 off shore, BMv3 on shore [17], and a mathematical interpolation in between. (b) Final bed elevation with the addition of the OMG gravity data. Elevation contours (white) every $400 \mathrm{~m}$. Brown line is the ice-ocean boundary. The red box delineates an example area where channel connectivity did not exist in the original bathymetry.

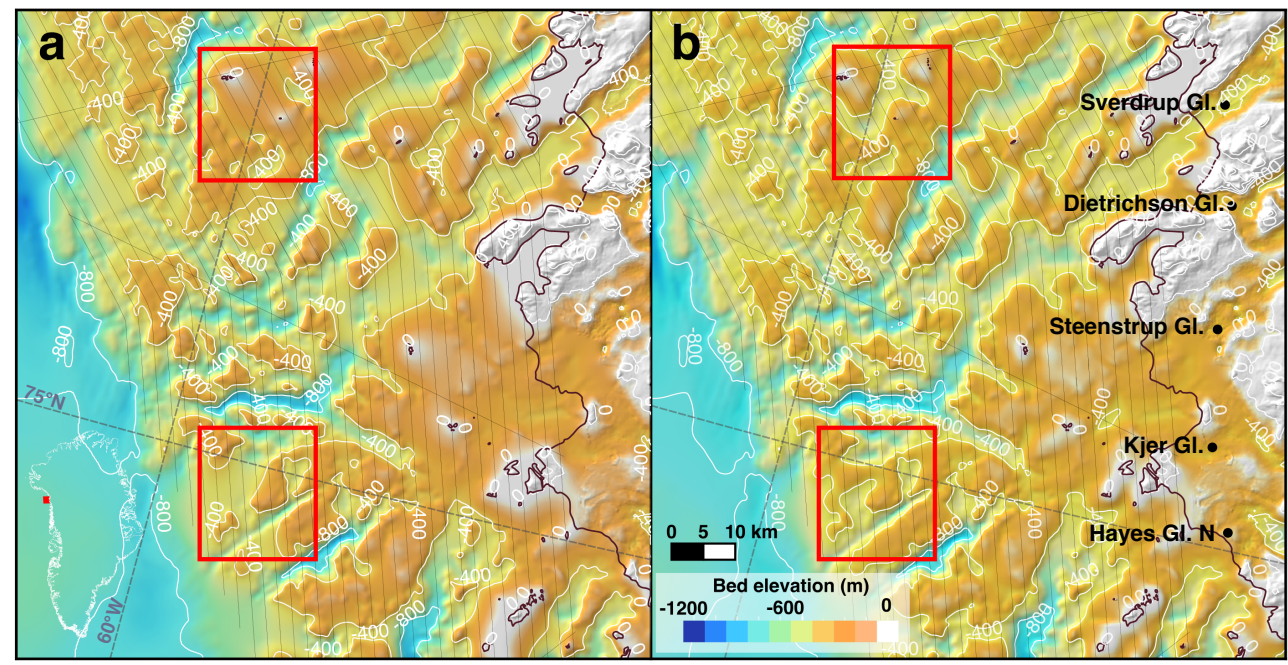

Figure 7. Region B in Figure 1a (a) Original bed elevation with MBES measurements, IBCAOv3 off shore, BMv3 on shore [17], and a mathematical interpolation in between. (b) Final bed elevation with the addition of the OMG gravity data. Elevation contours (white) every $400 \mathrm{~m}$. Brown line is the ice-ocean boundary. Red boxes delineate example areas where channel connectivity did not exist in the original bathymetry. 




Figure 8. Region $\mathrm{C}$ in Figure 1a (a) Bed elevation combining MBES measurements, IBCAOv3 off shore, $\mathrm{BMv} 3$ on shore [17], and a mathematical interpolation in between. (b) Bed elevation using an inversion of the OMG gravity data. Elevation contours (white) every $400 \mathrm{~m}$. Brown line is the ice-ocean boundary. Red boxes delineate areas where channel connectivity did not exist in the prior bathymetry. 


\section{Discussion}

The gravity method is a passive geophysical remote sensing technique that exploits the relationship between gravity anomalies, bed elevation, and density. Because of inherent ambiguities in the inversion, the solution is not unique. Here, we employ additional constraints with MBES data to reduce the uncertainty in our solution. We map bathymetry at a 2-km spacing, with an accuracy of $\pm 60 \mathrm{~m}$. While this measurement performance is less than that achievable with MBES (25 m spacing, 1-2 m vertical for the OMG data), the gravity data is critical to fill data gaps. In IBCAOv3, large expanses of nearly flat, shallow sea floor on the continental shelf make it impossible for subsurface AW to reach the glaciers in a numerical model of ocean circulation. The new bathymetry reveals a network of channels on the seafloor that are deep enough to host AW and connected well enough to enable its transport to the glaciers. We attribute the existence of these troughs to glacial erosion over many successive glacial cycles, as in other parts of Greenland (e.g., [30-33]). Most of these channels are 5 to $10 \mathrm{~km}$ wide, and 400-600 m deep. We also identify several areas where the seafloor in front of the glaciers is shallow, e.g., Nordenskiold, Steenstrup, Kjer, and Hayes N, hence access from warm, subsurface AW is limited.

We note that the prominent east-west gravity gradient along the NW coast of Greenland (Figure 1b), which reflects variations in the lithosphere from the outer shelf to the fjords of NW Greenland [34], does not affect the inversion because we have enough MBES data to constrain the solution. The 3-D gravity inversion would be hard to perform in the absence of MBES data of the outer shelf. Long-wave length contributions to the observed field, which do not influence the response of the gravity field to bathymetric variation, are successfully removed by DC shift method. In regions where the density of the seafloor materials is variable, the uncertainties of the models presented here will be greater than for models that account for the variation of density structure within the shallow subsurface.

Our results show that the outer shelf of NW Greenland is incised by a series of troughs that extend from the fjords and feed into major cross-shelf troughs of the mid to outer shelf, which are prominent features up to $250 \mathrm{~km}$ long and $100 \mathrm{~km}$ wide, namely the: (1) North Melville Bay Trough (NMBT), (2) Melville Bay Trough (MBT) and (3) South Melville Bay Trough (SMBT) (Figure 9) [34,35]. In contrast, the inner shelf troughs are 5 to $10 \mathrm{~km}$ wide, 400 to $1200 \mathrm{~m}$ deep, and U-shaped (not shown in the figures). Deep, U-shaped troughs on the inner shelf (Figures 6-8) are tributary or second-order troughs excavated by corridors of fast-flowing ice that extended from the fjords to the major cross-shelf troughs. The ice from the fjords beyond Docker Smith flowed in a westerly direction toward NMBT instead of MBT [35]. The ice from Rink to Illullip glaciers flowed in a southwesterly direction toward MBT. The ice from Cornell to Upernavik glaciers flowed into the SMBT trough.

The outer shelf of NW Greenland, which was shallow and flat in IBCAOv3, includes deep channels. Directly seaward of Sverdrup Glacier, we have a trough $600 \mathrm{~m}$ deep instead of $300 \mathrm{~m}$ in BMv3/IBCAOv3. Similarly, we identify major troughs seaward of Upernavik, Kakifaat, Ussing Brae, Illullip, Alison and South Hayes, and Hayes that provide pathways for AW to reach the glaciers. Farther north, the troughs in front of Kjer and Steenstrup, Sverdrup, Nansen, King Oscar and Issuusarsuit, Nordenskiöld, Rink and Docker Smith are relatively shallow. For several glaciers, the troughs on the continental shelf are better defined and connected in the gravity solution than in BMv3, e.g., Illullip, Hayes, Sverdrup, Nordernskiöld and Docker Smith glaciers. Confirming the connectivity of channels deeper than 250-300 $\mathrm{m}$ is important because this is the depth beyond which AW resides [9]. Many channels not connected in BMv3 are connected in the new map. While we cannot identify the effective pathway of AW without using a numerical ocean model and comparing the results with temperature/salinity data in the ocean, the bathymetry product is sufficient to identify pathways conducive to AW transport in some areas and natural blocks in others. 


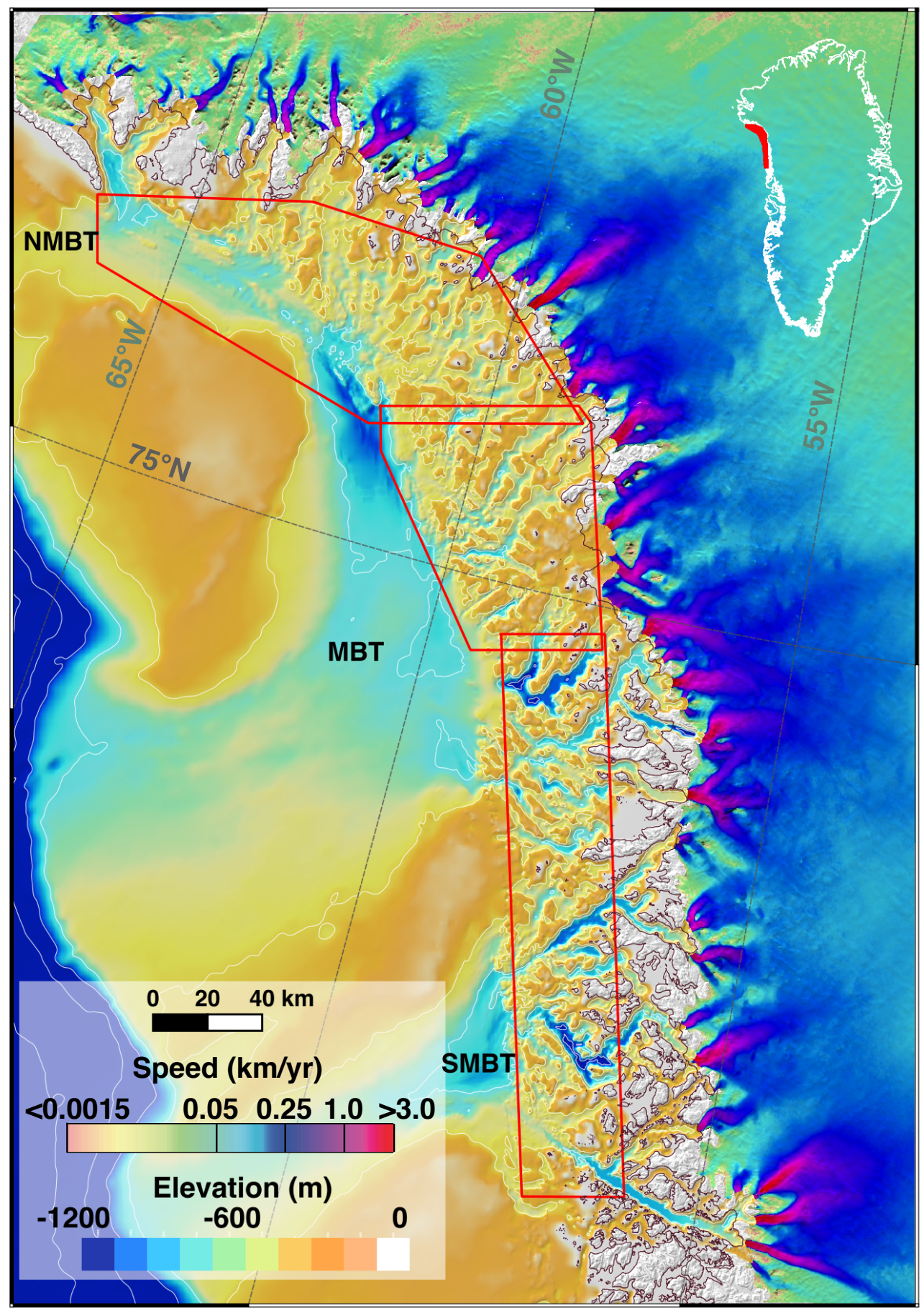

Figure 9. Bed elevation after OMG gravity inversion over regions in red boxes. Elevation contours (white) are every $400 \mathrm{~m}$. Brown line is the ice-ocean boundary. Ice velocity on land ice. NMBT = North Melville Bay Trough, MBT = Melville Bay Trough, and SMBT = South Melville Bay Trough.

We find that troughs are deep and wide in the southern part of the domain (e.g., Upernavik, Kakivfaat, Ussing Brae, Illullip, Alison and South Hayes) and in some cases even "over-deepened" by several hundred meters as in the Umanaq fjord system [36]. North of Hayes, the channels are less well developed and do not coalesce with other channels as often. The troughs in front of Kjer and Steenstrup are shallow. We cannot identify a trough in front of Kong Oscar or Nansen glaciers with certainty, but note that the front of Kong Oscar has not been surveyed with MBES, which is difficult for gravity inversion to be constrained. The striking difference in channel characteristics between north (Melville Bay) and the south (Upernavik district) may be due to several factors. One factor is the make-up of the 
bedrock, since the geology of the two sectors is markedly different [37]. According to the geological map along the northwest Greenland coast, orthogneiss mapped in the north of the area and charnockite in the south. Another is the rate of ice production. The glaciers in the north drain smaller basins, with lower speed, which makes them less effective at bed erosion. In the south, the former ice streams drained larger basins, at greater speeds, hence with more rapid basal erosion [38]. In that context, the configuration of the continental shelf in NW Greenland is special and contrast markedly with isolated, broad, deep channels farther south, e.g., in central west and southwest Greenland [17].

The new bathymetry will be essential to enable ocean numerical models to identify the pathways for AW to reach the glacial fjords, which in turn is critical to understand the ocean thermal forcing on the glaciers, their past and future evolution, and the role of the ocean on ice sheet mass balance. The differences between IBCAOv3 and the OMG-derived gravity inversion are significant, i.e., measured in many hundreds of meters, with enhanced connectivity of the channels and potential for hosting and transporting AW water.

Our study demonstrates the practicality of using airborne, high precision gravity surveys to map sea floor bathymetry over vast territories at a spatial resolution of $2 \mathrm{~km}$ and a vertical uncertainty of $60 \mathrm{~m}$. The approach requires a network of bathymetric observations for ground control. The results may eventually be improved with tailored, additional MBES data, especially now that the location of deep troughs is known.

\section{Conclusions}

In this study, we present a novel 3-D inversion of the OMG gravity data collected in NW Greenland to infer the bathymetry of the continental shelf from its western edge to the entry of the glacial fjords. The novel mapping provides details of the fjords and channels that are critical to understand ocean heat transport across the shelf, conduct a modeling of ocean circulation, and subsequently improve model projection of ice sheet evolution. The new bathymetric solution will be included in BedMachinev4 and is readily available at the OMG web site (http:/ / omg.jpl.nasa.gov). Our study demonstrates that high-resolution airborne gravity surveys provide a useful alternative to sea floor mapping in extensive areas with ice-filled waters. Future MBES data collection will remain key to improving the precision of the results locally, but the bathymetry products provided as a result of the OMG gravity data are already of sufficient quality to make major progress in understanding ocean heat exchange along the ice sheet periphery for the first time.

Author Contributions: Conceptualization, L.A., E.R., R.M., K.T. \& J.W.; Methodology, L.A., R.M., E.R. \& K.T.; Data processing \& validation, L.A., R.M., E.R. \& K.T.; Writing-Original Draft Preparation, L.A. \& E.R.; Writing一Review \& Editing, L.A., E.R., R.M., K.T. \& J.W.; Supervision, E.R., K.T. \& J.W.

Funding: This research was funded by National Aeronautics and Space Administration, and the grant number is 1528152 .

Acknowledgments: This work was performed in the Department of Earth System Science, University of California Irvine, at the Columbia University's Lamont Doherty Earth Observatory, and at Caltech's Jet Propulsion Laboratory. We thank the technical personnel from Sander Geophysics Ltd. (Ottawa, ON, Canada) and its aircraft pilots from conducting the gravity survey of NW Greenland in 2016, the crew of TerraSond Ltd. (Palmer, AK, USA) and M/V Cape Race, and Access Arctic for conducting the bathymetric surveys in 2016 and 2017.

Conflicts of Interest: The authors declare no conflict of interest.

\section{References}

1. Rignot, E.; Velicogna, I.; Van Den Broeke, M.R.; Monaghan, A.; Lenaerts, J. Acceleration of the contribution of the Greenland and Antarctic ice sheets to sea level rise. Geophys. Res. Lett. 2011, 38. [CrossRef]

2. Shepherd, A.; Ivins, E.R.; Geruo, A.; Barletta, V.R.; Bentley, M.J.; Bettadpur, S.; Briggs, K.H.; Bromwich, D.H.; Forsberg, R.; Galin, N.; et al. A Reconciled Estimate of Ice-Sheet Mass Balance. Science 2012, 338, 1183-1189. [CrossRef] 
3. Van den Broeke, M.R.; Enderlin, E.M.; Howat, I.M.; Kuipers Munneke, P.; Noël, B.P.Y.; van de Berg, W.J.; van Meijgaard, E.; Wouters, B. On the recent contribution of the Greenland ice sheet to sea level change. Cryosphere 2016, 10, 1933-1946. [CrossRef]

4. McMillan, M.; Leeson, A.; Shepherd, A.; Briggs, K.; Armitage, T.; Hogg, A.; Munneke, P.K.; Broeke, M.V.D.; Noël, B.; Berg, W.J.V.D.; et al. A high resolution record of Greenland mass balance. Geophys. Res. Lett. 2016, 7002-7010. [CrossRef]

5. Velicogna, I.; Sutterley, T.C.; Van Den Broeke, M.R. Regional acceleration in ice mass loss from Greenland and Antarctica using GRACE time-variable gravity data. Geophys. Res. Lett. 2014, 41, 8130-8137. [CrossRef]

6. Rignot, E.; Kanagaratnam, P. Changes in the Velocity Structure of the Greenland Ice Sheet. Science 2006, 311, 986-990. [CrossRef] [PubMed]

7. Holland, D.M.; Thomas, R.H.; de Young, B.; Ribergaard, M.H.; Lyberth, B. Acceleration of Jakobshavn Isbræ triggered by warm subsurface ocean waters. Nat. Geosci. 2008, 1, 659-664. [CrossRef]

8. Motyka, R.J.; Truffer, M.; Fahnestock, M.; Mortensen, J.; Rysgaard, S.; Howat, I. Submarine melting of the 1985 Jakobshavn Isbræ floating tongue and the triggering of the current retreat. J. Geophys. Res. Earth Surf. 2011, 116. [CrossRef]

9. Rignot, E.; Fenty, I.; Menemenlis, D.; Xu, Y. Spreading of warm ocean waters around Greenland as a possible cause for glacier acceleration. Ann. Glaciol. 2012, 53, 257-266. [CrossRef]

10. Murray, T.; Scharrer, K.; James, T.D.; Dye, S.R.; Hanna, E.; Booth, A.D.; Selmes, N.; Luckman, A.; Hughes, A.L.C.; Cook, S.; et al. Ocean regulation hypothesis for glacier dynamics in southeast Greenland and implications for ice sheet mass changes. J. Geophys. Res. Earth Surf. 2010, 115. [CrossRef]

11. Straneo, F.; Sutherland, D.A.; Holland, D.; Gladish, C.; Hamilton, G.S.; Johnson, H.L.; Rignot, E.; Xu, Y.; Koppes, M. Characteristics of ocean waters reaching greenland's glaciers. Ann. Glaciol. 2012, 53, $202-210$. [CrossRef]

12. Straneo, F.; Heimbach, P. North Atlantic warming and the retreat of Greenland's outlet glaciers. Nature 2013, 504, 36-43. [CrossRef] [PubMed]

13. Morlighem, M.; Rignot, E.; Mouginot, J.; Seroussi, H.; Larour, E. Deeply incised submarine glacial valleys beneath the Greenland ice sheet. Nat. Geosci. 2014, 7, 18-22. [CrossRef]

14. Fenty, I.; Willis, J.; Khazendar, A.; Dinardo, S.; Forsberg, R.; Fukumori, I.; Holland, D.; Jakobsson, M.; Moller, D.; Morison, J.; et al. Oceans Melting Greenland: Early Results from NASA's Ocean-Ice Mission in Greenland. Oceanography 2016, 29, 72-83. [CrossRef]

15. Morlighem, M.; Rignot, E.; Willis, J. Improving Bed Topography Mapping of Greenland Glaciers Using NASA's Oceans Melting Greenland (OMG) Data. Oceanography 2016, 29, 62-71. [CrossRef]

16. Jakobsson, M.; Mayer, L.; Coakley, B.; Dowdeswell, J.A.; Forbes, S.; Fridman, B.; Hodnesdal, H.; Noormets, R.; Pedersen, R.; Rebesco, M.; et al. The International Bathymetric Chart of the Arctic Ocean (IBCAO) Version 3.0. Geophys. Res. Lett. 2012, 39. [CrossRef]

17. Morlighem, M.; Williams, C.N.; Rignot, E.; An, L.; Arndt, J.E.; Bamber, J.L.; Catania, G.; Chauché, N.; Dowdeswell, J.A.; Dorschel, B.; et al. BedMachine v3: Complete Bed Topography and Ocean Bathymetry Mapping of Greenland from Multibeam Echo Sounding Combined with Mass Conservation. Geophys. Res. Lett. 2017, 44, 11051-11061. [CrossRef] [PubMed]

18. Greenbaum, J.S.; Blankenship, D.D.; Young, D.A.; Richter, T.G.; Roberts, J.L.; Aitken, A.R.A.; Legresy, B.; Schroeder, D.M.; Warner, R.C.; van Ommen, T.D.; et al. Ocean access to a cavity beneath Totten Glacier in East Antarctica. Nat. Geosci. 2015, 8, 294-298. [CrossRef]

19. Gourlet, P.; Rignot, E.; Rivera, A.; Casassa, G. Ice thickness of the northern half of the Patagonia Icefields of South America from high-resolution airborne gravity surveys. Geophys. Res. Lett. 2016, 43, 241-249. [CrossRef]

20. An, L.; Rignot, E.; Elieff, S.; Morlighem, M.; Millan, R.; Mouginot, J.; Holland, D.M.; Holland, D.; Paden, J. Bed elevation of Jakobshavn Isbrae, West Greenland, from high-resolution airborne gravity and other data. Geophys. Res. Lett. 2017, 44, 3728-3736. [CrossRef]

21. Millan, R.; Rignot, E.; Mouginot, J.; Wood, M.; Bjørk, A.A.; Morlighem, M. Vulnerability of Southeast Greenland Glaciers to Warm Atlantic Water from Operation IceBridge and Ocean Melting Greenland Data. Geophys. Res. Lett. 2018, 45, 2688-2696. [CrossRef] [PubMed] 
22. Argyle, M.; Ferguson, S.; Sander, L.; Sander, S. AIRGrav results: A comparison of airborne gravity survey data with GSC test site data. In SEG Technical Program Expanded Abstracts 2000; Society of Exploration Geophysicists: Tulsa, OK, USA, 2000; pp. 435-437, doi:10.1190/1.1816088.

23. Sander, S.; Argyle, M.; Elieff, S.; Ferguson, S.; Lavoie, V.; Sander, L. The AIRGrav airborne gravity system. CSEG Rec. 2005, 30, 32-36.

24. OMG Mission. Conductivity, Temperature and Depth (CTD) Data from the Ocean Survey, verion 0.1; OMG SDS: Pasadena, CA, USA, 2016.

25. Chen, C.; Millero, F.J. Speed of sound in seawater at high pressures. J. Acoust. Soc. Am. 1977, 62, 1129-1135. [CrossRef]

26. Parker, R. The rapid calcuation of potential anomalies. Geophys. J. 1973, 31, 447-455. [CrossRef]

27. Tinto, K.J.; Bell, R.E. Progressive unpinning of Thwaites Glacier from newly identified offshore ridge: Constraints from aerogravity. Geophys. Res. Lett. 2011, 38. [CrossRef]

28. Muto, A.; Anandakrishnan, S.; Alley, R.B. Subglacial bathymetry and sediment layer distribution beneath the Pine Island Glacier ice shelf, West Antarctica, modeled using aerogravity and autonomous underwater vehicle data. Ann. Glaciol. 2013, 54, 27-32. [CrossRef]

29. Wood, M.; Rignot, E.; Fenty, I.; Menemenlis, D.; Millan, R.; Morlighem, M.; Mouginot, J.; Seroussi, H. Ocean-induced melt triggers glacier retreat in Northwest Greenland. Geophys. Res. Lett. 2018, 45, 8334-8342. [CrossRef]

30. Syvitski, J.; Burrell, D.; Skei, J. Fjords: Processes and Products; Springer: New York, NY, USA, 1987.

31. Dowdeswell, J.; Whittington, R.; Marienfeld, P. The origin of massive diamicton facies by iceberg rafting and scouring, Scoresby Sund, East Greenland. Sedimentology 1994, 41, 21-35. [CrossRef]

32. Dowdeswell, J.A.; Batchelor, C.L.; Hogan, K.A.; Schenke, H.W. Nordvestfjord: A major East Greenland fjord system. Geol. Soc. Lond. Mem. 2016, 46, 43-44. [CrossRef]

33. Hjelstuen, B.O.; Kjennbakken, H.; Bleikli, V.; Ersland, R.A.; Kvilhaug, S.; Euler, C.; Alvheim, S. Fjord stratigraphy and processes—Evidence from the NE Atlantic Fensfjorden system. J. Quat. Sci. 2013, 28, 421-432. [CrossRef]

34. Batcherlor, C.L.; Dowdeswell, J.A.; Rignot, E. Submarine landforms reveal varying rates and styles of deglaciation in North-West Greenland fjords. Mar. Geol. 2017, 402, 60-80. [CrossRef]

35. Slabon, P.; Dorschel, B.; Jokat, W.; Myklebust, R.; Hebbeln, D.; Gebhardt, C. Greenland ice sheet retreat history in the northeast Baffin Bay based on high-resolution bathymetry. Quat. Sci. Rev. 2016, 154, 182-198. [CrossRef]

36. Rignot, E.; Fenty, I.; Xu, Y.; Cai, C.; Velicogna, I.; Cofaigh, C.; Dowdeswell, J.A.; Weinrebe, W.; Catania, G.; Duncan, D. Bathymetry data reveal glaciers vulnerable to ice-ocean interaction in Uummannaq and Vaigat glacial fjords, west Greenland. Geophys. Res. Lett. 2016, 43, 2667-2674. [CrossRef]

37. Pedersen, M.; Weng, W.L.; Keulen, N.; Kokfelt, T.F. A new seamless digital 1:500,000 scale geological map of Greenland. Geol. Surv. Den. Greenl. Bull. 2013, 28, 65-68.

38. Batchelor, C.L.; Dowdeswell, J.A. Lateral shear-moraines and lateral marginal-moraines of palaeo-ice streams. Quat. Sci. Rev. 2016, 151, 1-26. [CrossRef]

(C) 2019 by the authors. Licensee MDPI, Basel, Switzerland. This article is an open access article distributed under the terms and conditions of the Creative Commons Attribution (CC BY) license (http://creativecommons.org/licenses/by/4.0/). 